\title{
Akses dan Penggunaan TIK pada Rumah Tangga dan Individu di Kecamatan Barru
}

\section{ICT Access and Use by Households and Individuals in Barru Sub-district}

\author{
Rahmita Saleh $^{1)}$, Soraya Firdausy ${ }^{2}$, Yulhaidir $^{3)}$ \\ Program Studi Ilmu Komunikasi Fakultas Ekonomi dan Ilmu-Ilmu Sosial Universitas Fajar Makassar \\ Jl. Prof. Dr. Abdurrahman Basalamah No.101, Makassar, 90123, Telp/Fax: 0411-4460084 \\ rahmitasaleh@unifa.ac.id ${ }^{1)}$, soraya@unifa.ac.id²),yulhaidir@unifa.ac.id ${ }^{3)}$
}

\begin{abstract}
Abstrak - Bagi negara berkembang seperti Indonesia, mengukur akses dan penggunaan TIK adalah kunci untuk memantau kemajuan negara menuju masyarakat informasi dan merupakan bagian penting untuk analisis dan perencanaan kebijakan bidang TIK dan kebijakan terkait lainnya. Dalam kaitannya dengan perancangan kebijakan, penting untuk melakukan pengukuran TIK di Kecamatan Barru Kabupaten Barru karena masuk dalam Kawasan Perdesaan Prioritas Nasional (KPPN), sebuah kawasan perdesaan yang ditetapkan oleh Bappenas dan Kemenko PMK guna mengurangi kesenjangan antara desa dan kota dalam berbagai sektor. Dalam agenda kebijakan KPPN, 4 dari 5 Desa di Kecamatan Barru termasuk didalamnya. Pengukuran ini dilakukan dengan tujuan untuk mendapatkan data statistik yang komprehensif dan sebanding untuk mendukung keputusan kebijakan pemerintah dan industri dalam bidang TIK untuk mengurangi kesenjangan digital di wilayah tersebut. Metode yang digunakan adalah survey terhadap 384 responden. Teknik pengumpulan data dilakukan melalui wawancara tatap muka dengan menggunakan kuesoiner. Indikator yang digunakan mengacu pada International Telecommunication Union (ITU) pada tingkat rumah tangga dan individu. Hasil pengukuran menunjukkan bahwa akses dan penggunaan terhadap telepon seluler dan internet sangat tinggi di Kecamatan Barru, namun akses dan penggunaan komputer masih rendah.
\end{abstract}

Kata Kunci: Akses dan Penggunaan TIK, Kecamatan Barru, KPPN

\begin{abstract}
For developing country like Indonesia, measuring access and using ICTs are key to monitoring the progress of the country towards an information society and an important part of the analysis and planning of ICT policy and other related policies. Related to policy design, it is important to measure ICT in Barru Subdistrict, Barru Regency because it is included in the Kawasan Perdesaan Prioritas Nasional/KPPN, a rural area established by Bappenas and Kemenko PMK to reduce disparities between villages and cities in various sectors. In the KPPN policy agenda, 4 of the 5 villages in Barru Sub-district are included. This measurement was carried out with the aim of obtaining comprehensive and comparable statistical data to support government and industry policy decisions in the field of ICT to reduce the digital divide in the region. The method used is a survey of 384 respondents. The technique of collecting data is done through face-to-face interviews using questionnaires. The indicators used refer to the International Telecommunication Union (ITU) at the household and individual level. The measurement results show that access to and use of cellular and internet telephones is very high in Barru Sub-district, but access and use of computers is still low.
\end{abstract}

Keywords: ICT Access and Use, Barru Sub-district, KPPN

\section{Pendahuluan}

Ketersediaan infrastruktur teknologi informasi dan komunikasi (TIK) dan penggunaannya terus tumbuh di seluruh dunia. Perkembangannya berlangsung pesat dan memberikan dampak yang besar pada perorangan, bisnis dan pemerintah. TIK mengurangi kendala jarak fisik, jarak psikologis, dan jarak ekonomi, yang memungkinkan orang untuk berkomunikasi dan meyumbangkan informasi dan gagasan secara bebas dalam waktu sekejap, serta mampu mendorong inovasi dan kreativitas, menambah lapangan kerja dan meningkatkan produktivitas sebuah negara (Darwanto, 2012).
Perkembangan TIK juga dikenal sebagai era informasi yang ditandai dengan berkembangnya masyarakat dunia yang berpengetahuan. Perserikatan Bangsa-Bangsa melalui konferensi tingkat tinggi yang diberi nama KTT Masyarakat Informasi telah menyetujui terbentuknya masyarakat informasi di seluruh negara-negara dunia untuk mengembangkan segala kebutuhan yang berkaitan dengan TIK. KTT ini ditujukan untuk menumbuhkan bangsa-bangsa yang sadar dan cepat menangkap informasi sehingga akan berdampak pada pertumbuhan pengetahuanpengetahuan yang menjadi dasar untuk terbentuknya masyarakat berpengetahuan di seluruh belahan dunia. 
Sehingga, tidak ada lagi negara berkembang dan terbelakang dari segi pengetahuan dan kemandirian.

Ukuran tingkat pembangunan teknologi informasi dan komunikasi, kesenjangan digital dan potensi pengembangan TIK di suatu wilayah adalah Indeks Pembangunan Teknologi Informasi dan Komunikasi (IP-TIK). Semakin tinggi nilai indeks menunjukkan potensi dan progress pembangunan TIK suatu wilayah lebih optimum. Sebaliknya, semakin rendah nilai indeks menunjukkan pembangunan TIK masih belum optimum (Berita Resmi Statistik BPS, 2018).

Berdasarkan data BPS Tahun 2018, IP-TIK Indonesia pada tahun 2017 sebesar 4,99 pada skala 010. Indeks ini naik dari tahun sebelumnya yaitu 4,34 pada tahun 2016 dan 3,88 pada tahun 2015 (Fauzi, 2018). Indeks ini belum dinilai optimum karena nilai indeks masih rendah. Meskipun sudah ada beberapa provinsi yang mencapai indeks di atas 5 (tinggi) seperti DKI Jakarta 7,41 dan Yogyakarta 6,12. Sulawesi Selatan berada dalam kategori sedang dengan nilai indeks 4,86 dan masih berada di bawah indeks nasional.

Pengukuran indeks ini mengacu pada indikator yang disusun oleh International Telecommunication Union (ITU). Sebuah badan khusus yang dibentuk PBB untuk mengembangkan standar teknis yang memastikan jaringan dan teknologi terhubung dengan lancar, dan berusaha untuk meningkatkan akses ke TIK untuk masyarakat yang kurang terlayani di seluruh dunia (International Telecommunication Union, 2016).

Terdapat 23 indikator pengukuran yang disusun oleh ITU yang disesuaikan dengan perubahanperubahan yang terjadi khususnya yang ditimbulkan oleh penggunaan internet. Setiap indikator yang diukur adalah elemen kunci, bukan hanya karena membantu untuk mengumpulkan data statistik tetapi juga membantu dalam memahami pentingnya mengidentifikasi dan memantau aspek-aspek dari kesenjangan digital.

Masih rendahnya nilai indeks IP-TIK di Indonesia, dan di Sulawesi Selatan secara khusus, di tengah perkembangan teknologi yang pesat secara global, mendorong pentingnya perhatian pada pengukuran akses dan penggunaan TIK pada skala regional untuk mendapatkan data yang spesifik sehingga mampu mengidentifikasi permasalahan TIK yang dialami pada masing-masing wilayah.

Damanik (2016) dalam risetnya mengenai akses dan penggunaan TIK di 8 provinsi pada wilayah kerja Balai Besar Pengkajian dan Pengembangan Komunikasi dan
Informatika Medan menyatakan bahwa, secara umum pengukuran TIK dalam bentuk survey ini bertujuan untuk mengumpulkan, mengolah, dan menyajikan data mengenai tren TIK sehingga diharapkan data yang diperoleh dapat meningkatkan pemahaman para pengambil keputusan tentang berbagai kondisi yang perlu ditangani. Sehingga kebijakan pengelolaan dan evaluasi TIK untuk pembangunan di berbagai bidang dapat lebih terarah.

Dalam survey lainnya, Yusrizal (2016) menemukan permasalahan yang dialami di wilayah perbatasan Indonesia adalah keterbatasan infrastruktur pendidikan, infrastruktur fisik seperti jalan, maupun infrastruktur pendukung seperti jaringan listrik sangat mempengaruhi secara signifikan perkembangan teknologi informasi di wilayah tersebut.

Selain permasalahan indeks TIK yang rendah, beberapa wilayah di Sulawesi Selatan juga masuk dalam Kawasan Perdesaan Prioritas Nasional (KPPN), sebuah kawasan perdesaan yang ditetapkan oleh Bappenas dan Kemenko PMK yang dibentuk guna mengurangi kesenjangan antara desa dan kota dalam berbagai sektor. Wilayah tersebut adalah Kabupaten Barru, Kabupaten Pinrang, Kabupaten Sidrap dan Kabupaten Luwu (Lampiran, 2018).

Sehingga untuk mengurangi satu kesenjangan yaitu kesenjangan digital, perlu dilakukan sebuah survey terhadap akses dan penggunaan TIK pada wilayah tersebut untuk mendukung pengambilan kebijakan terhadap peningkatan akses TIK untuk msyarakat yang tepat dan lebih terarah.

Wilayah yang di survey pada tahap pertama adalah Kecamatan Barru yang terletak di Kabupaten Barru dimana terdapat 4 Desa yang masuk dalam agenda KPPN, yaitu Desa Tompo, Galung, Palakka, dan Anabanua.

Pengukuran TIK yang diukur secara regional ini di tingkat rumah tangga dan individu bertujuan untuk mendapatkan data statistik dari Kecamatan Barru yang dapat diandalkan, komprehensif dan sebanding untuk mendukung keputusan kebijakan pemerintah dan industri dalam mengembangkan dan meningkatkan kualitas TIK di wilayah prioritas tersebut. Sehingga diharapkan hasil dari penelitian ini dapat dijadikan rujukan penyusunan kebijakan TIK untuk membangun sektor TIK di kawasan perdesaan dengan lebih terarah dan mampu mengurangi kesenjangan antar desa dan kota maupun kesenjangan digital.

\section{Metodologi Penelitian}


Penelitian ini menggunakan metode survei dengan jenis deskriptif (Kriyantono, 2010). Survei dilaksanakan pada bulan Juli tahun 2019 dengan teknik pengumpulan data melalui wawancara tatap muka menggunakan kuesioner.

Responden atau sumber data adalah individu dalam satu rumah tangga yang berada di Kecamatan Barru Kabupaten Barru Sulawesi Selatan yang memiliki jumlah rumah tangga sebanyak 9.581 (Badan Pusat Statistik Kab. Barru, 2018).

Sampel ditentukan berdasarkan rumus Slovin (Bungin, 2011) dengan sampling error 5\%, sehingga ditemukan besarnya sampel adalah 384 rumah tangga dengan responden untuk pengukuran di tingkat rumah tangga adalah individu yang berada dalam rumah tangga tersebut (dipilih secara bebas), sementara pengukuran di tingkat individu adalah individu yang lebih mampu mengakses dan menggunakan perangkat TIK (diacak).

Dalam proses pengumpulan data, teknik yang digunakan adalah proportional stratified sampling, dimana populasi dikelompokkan berdasarkan karaktristik tertentu dan sampel diperoleh sebanyak 0,97\% (jumlah sampel dibagi jumlah populasi/384 dibagi 9.581) dari setiap strata. Pengelompokan dilakukan berdasarkan stata Desa dan Kelurahan. Berikut ini adalah sebaran sampel penelitian:

Tabel 1 Sebaran Sampel Riset Akses dan Penggunaan TIK di Kecamatan Barru Tahun 2019

\begin{tabular}{clcc}
\hline No & Desa/Kelurahan & $\begin{array}{c}\text { Jumlah Rumah } \\
\text { Tangga }\end{array}$ & $\begin{array}{c}\text { Jumlah } \\
\text { Sampel }\end{array}$ \\
\hline 1 & Desa Anabanua & 463 & 18 \\
2 & Desa Tompo & 569 & 23 \\
3 & Desa Palakka & 745 & 30 \\
4 & Desa Galung & 476 & 19 \\
5 & Desa Siawung & 671 & 27 \\
6 & Kelurahan Sumpang & 2.370 & 95 \\
& Binangae & 1.299 & 52 \\
7 & Kelurahan & 1.221 & 49 \\
& Mangempang & 1.014 & 41 \\
8 & Kelurahan Coppo & 753 & 30 \\
9 & Kelurahan Tuwung & 9.581 & 384 \\
10 & Kelurahan Sepe'e & \multicolumn{2}{c}{} \\
\hline \multicolumn{2}{l}{ Total } & \multicolumn{2}{c}{} \\
(sumber: BPS Kabupaten Barru 2018; olahan peneliti)
\end{tabular}

Indikator ditentukan berdasarkan pengukuran yang disusun oleh International Telecommunication Union (ITU). Indikator yang digunakan adalah akses dan penggunaan TIK oleh rumah tangga dan individu edisi 2014 dan hasil revisi tahun 2016 dan 2018. Pengumpulan statistik TIK di tingkat rumah tangga dan individu mencerminkan kebutuhan metode statistik dan konsep yang mengikuti perubahan di bidang teknologi informasi dan komunikasi. Adapun indikator yang digunakan adalah:

Tabel 2 Indikator Pengukuran Akses dan Penggunaan TIK di Kecamatan Barru Tahun 2019

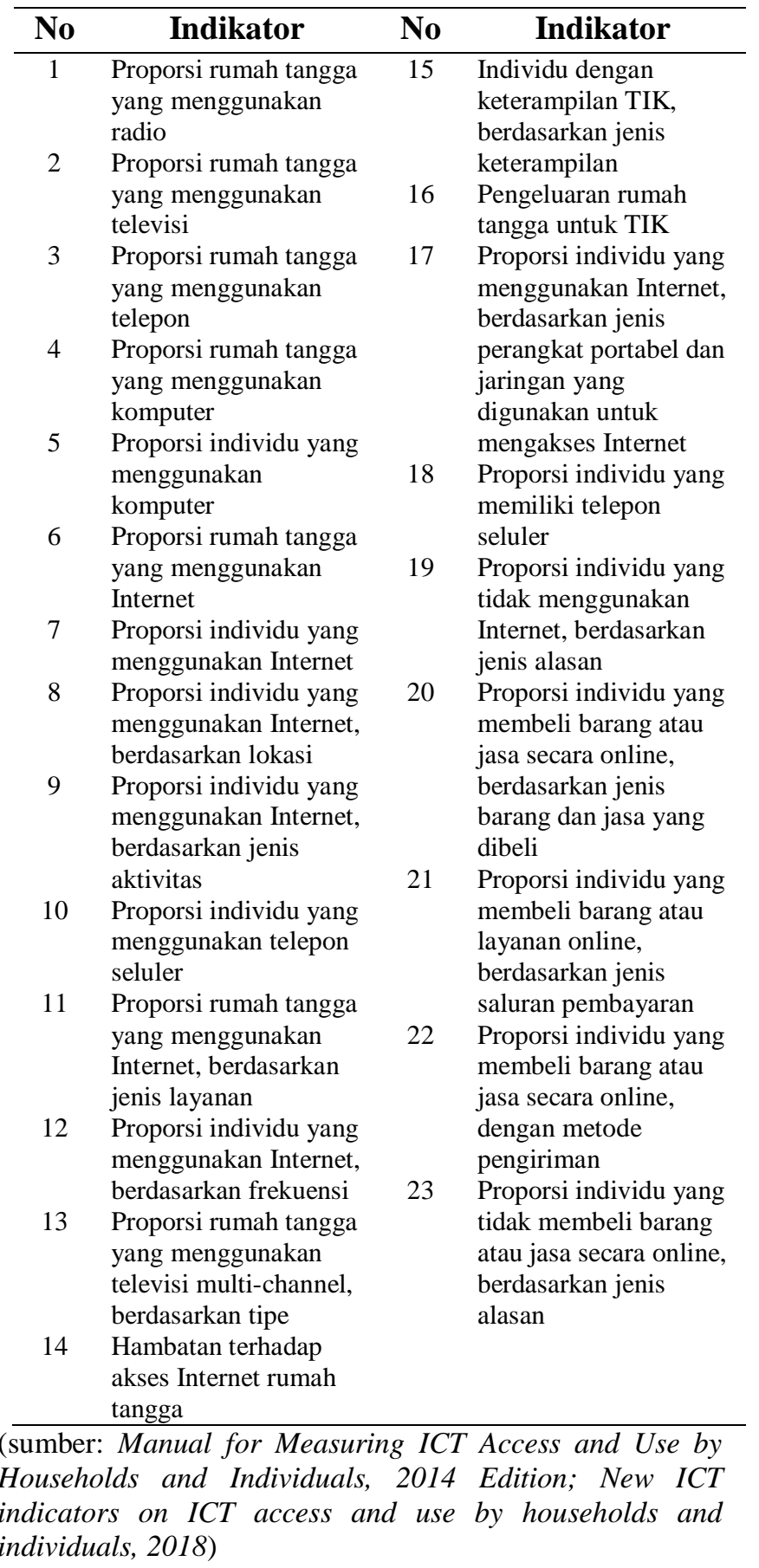

Penelitian ini diharapkan dapat menjadi rekomendasi peningkatan kualitas sektor TIK dan mengurangi kesenjangan digital dan antar wilayah di Kecamatan Barru. Rancangan penelitian ini dapat dilihat dalam gambar berikut: 


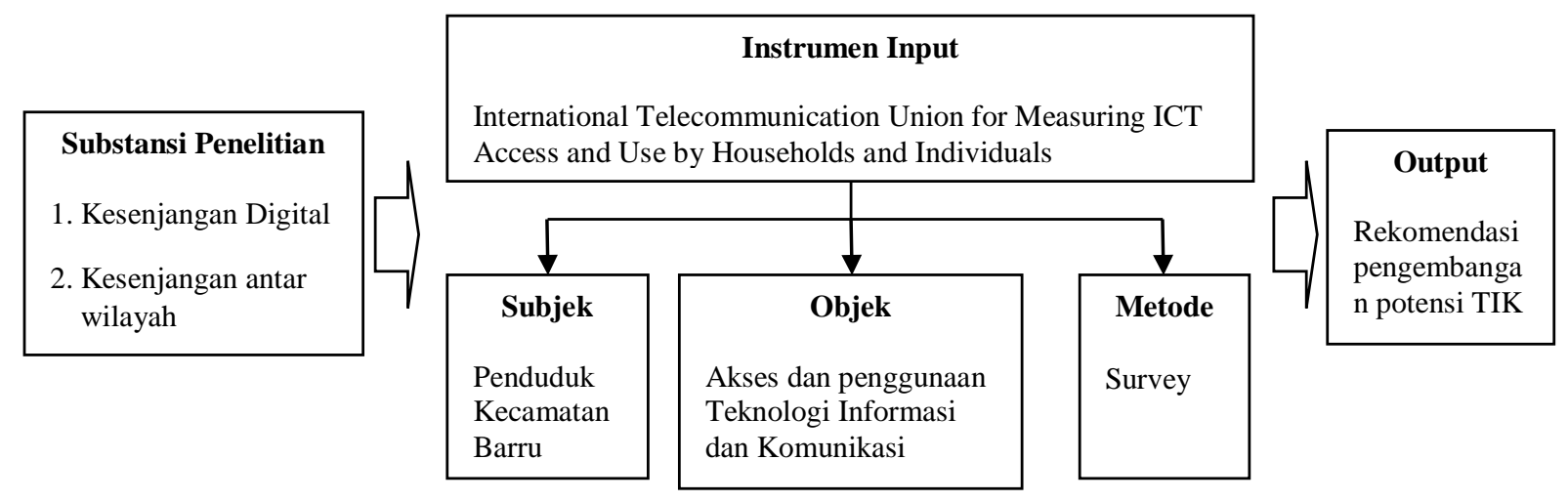

Gambar 1 Rancangan Penelitian

\section{HASIL DAN PEMBahasan}

Hasil survey terhadap 384 responden di Kecamatan Barru akan dideskripsikan dalam empat bagian, yaitu karakteristik rumah tangga, akses rumah tangga ke TIK, karakteristik individu, dan penggunaan TIK oleh individu.

\section{Karakteristik Rumah Tangga}

Karakteristik rumah tangga diukur dari dua aspek yaitu jumlah anggota keluarga dan komposisi rumah tangga yang memiliki anak usia di bawah 15 tahun atau tidak memiliki anak usia di bawah 15 tahun. Deskripsi jumlah anggota keluarga ditunjukkan dalam Gambar 2 di bawah ini:

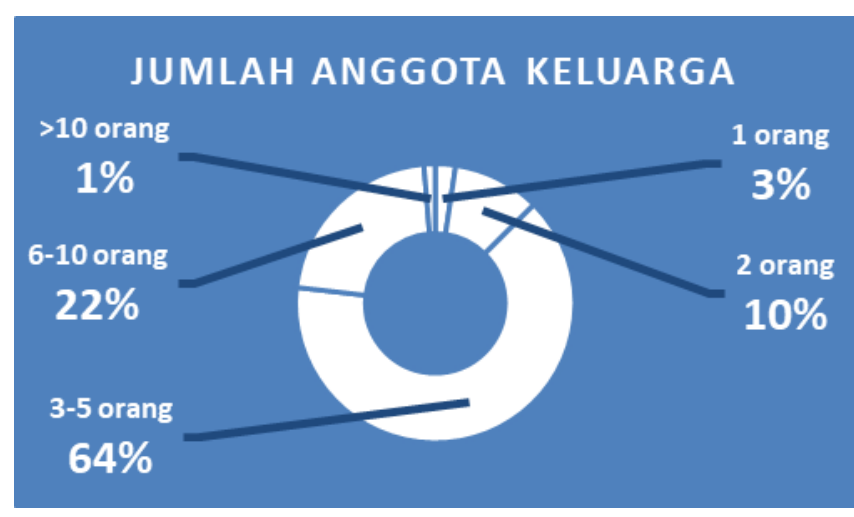

Gambar 2 Deskripsi Jumlah Anggota Keluarga

Gambar 2 menunjukkan bahwa jumlah anggota keluarga terbanyak berada pada rentang $3-5$ orang dalam sebuah rumah tangga yakni sebanyak 64\% (247 orang) dari total responden. Pengukuran terhadap jumlah anggota keluarga terkait dengan perangkat TIK atau layanan yang tersedia untuk digunakan oleh semua anggota keluarga dalam sebuah rumah tangga. Jumlah ini juga terkait dengan pengeluaran dan pola konsumsi sebuah rumah tangga terhadap perangkat dan layanan TIK. Secara proporsi, angka ini dapat diartikan proporsional dimana ketersediaan perangkat TIK dapat diakses secara merata oleh keseluruhan anggota keluarga.

Aspek lainnya adalah komposisi rumah tangga yang diukur berdasarkan adanya anak usia di bawah 15 tahun atau tidak adanya anak usia di bawah 15 tahun dalam sebuah rumah tangga. Deskripsi komposisi rumah tangga ditunjukkan dalam Gambar 3 berikut ini:

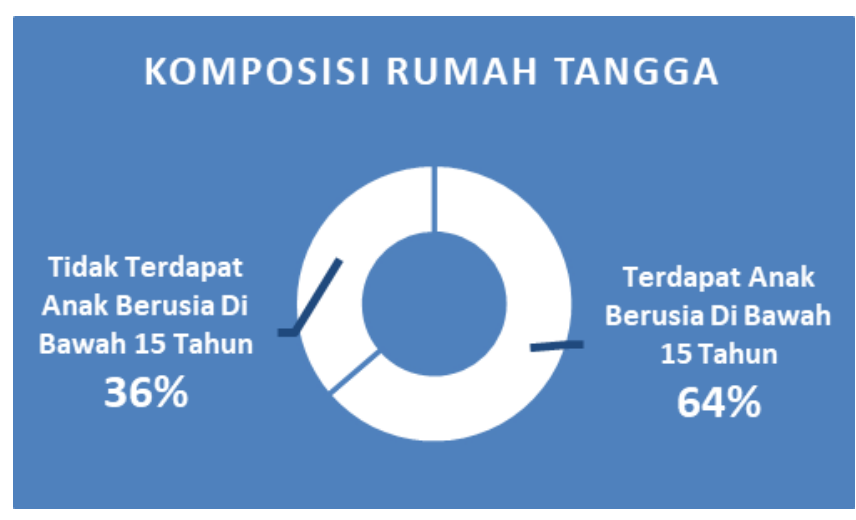

Gambar 3 Komposisi Rumah Tangga

Berdasarkan hasil survey, ditemukan bahwa $64 \%$ dari rumah tangga memiliki anak yang berusia di bawah 15 tahun. Usia ini merupakan usia "digital natives" yang berarti bahwa di usia tersebut keakraban dan pemahaman terhadap teknologi lebih besar karena telah menjadi bagian integral dari kehidupan mereka.

\section{Akses Rumah Tangga ke TIK}

Indikator akses rumah tangga terhadap TIK diukur berdasarkan tersedianya perangkat dan layanan yang meliputi radio, televisi, layanan televisi, saluran telepon kabel, telepon seluler, komputer, internet dan layanan internet. Indikator-indikator ini merujuk pada akses anggota rumah tangga ke peralatan dan layanan TIK (termasuk hambatan), dan bukan pada tingkatan individu. Gambaran deskripsi masing-masing indikator dapat dilihat pada gambar di bawah ini: 


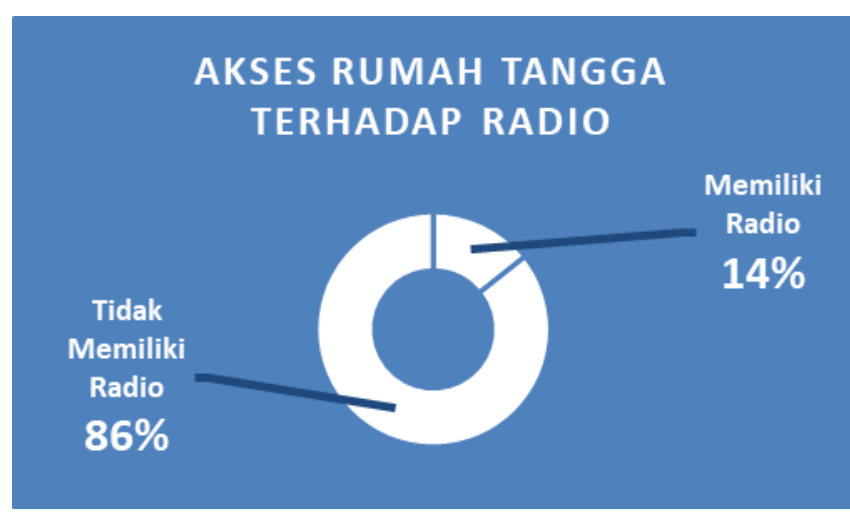

Gambar 4 Akses Rumah Tangga Terhadap Radio

Gambar 4 menunjukkan bahwa mayoritas rumah tangga di Kecamatan Barru tidak memiliki radio dengan persentase sebanyak $86 \%$. Berdasarkan survey yang dilakukan, mayoritas masyarakat tidak lagi menyediakan anggaran untuk membeli perangkat radio apabila perangkat mengalami kerusakan. Sehingga $14 \%$ rumah tangga yang masih memiliki radio adalah rumah tangga yang memiliki perangkat yang masih berada dalam kondisi bekerja namun sudah jarang dioperasikan.

Berbeda dengan akses terhadap radio, rumah tangga di Kecamatan Barru mayoritas memiliki televisi dengan persentase 95\%. Pada umumnya televisi dimiliki oleh setiap rumah tangga yang digunakan sebagai sarana hiburan dan mendapatkan informasi. Berikut persentasenya:

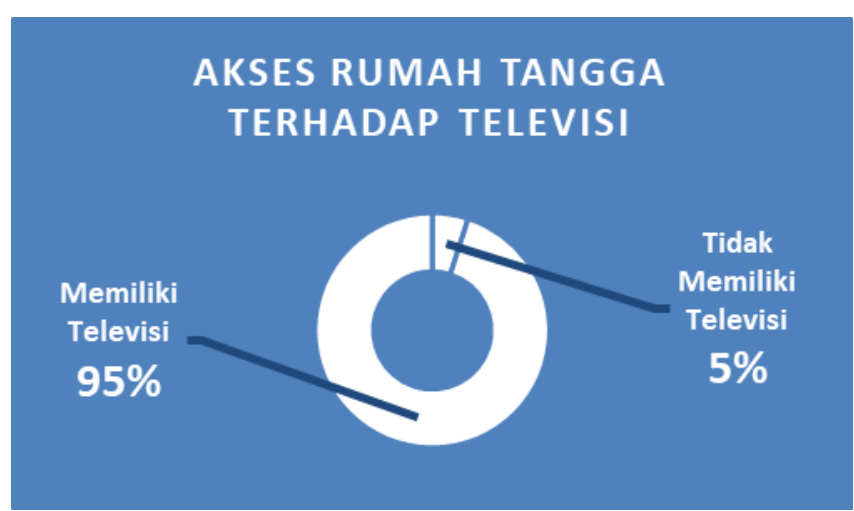

Gambar 5 Akses Rumah Tangga Terhadap Televisi

Layanan yang paling banyak digunakan adalah satelit (parabola) sebanyak 47\%. Layanan ini khususnya tersedia pada wilayah yang termasuk dalam Kawasan Perdesaan Prioritas Nasional yang berada di daerah pegunungan. Berikutnya adalah TV kabel sebanyak $43 \%$, antenna UHF sebanyak $9 \%$ dan layanan Internet-Protocol TV sebanyak 1\%. Berikut adalah gambaran ketersediaan layanan televisi pada rumah tangga di Kecamatan Barru:

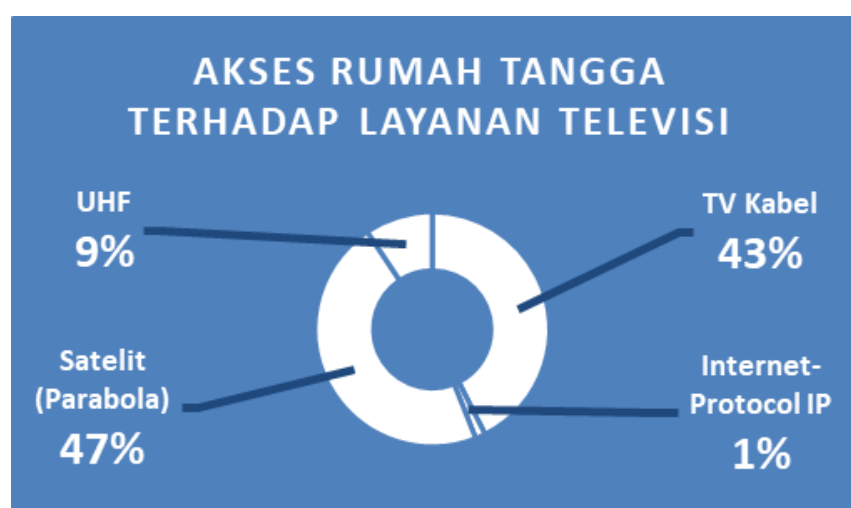

Gambar 6 Akses Rumah Tangga Terhadap Layanan Televisi

Indikator lainnya adalah akses rumah tangga terhadap perangkat saluran telepon kabel dan telepon seluler. Hampir sama dengan kepemilikan radio dan televisi, mayoritas rumah tangga sudah tidak lagi memiliki saluran telepon kabel namun mayoritas memiliki telepon seluler. Persentasenya dapat dilihat pada gambar di bawah ini:

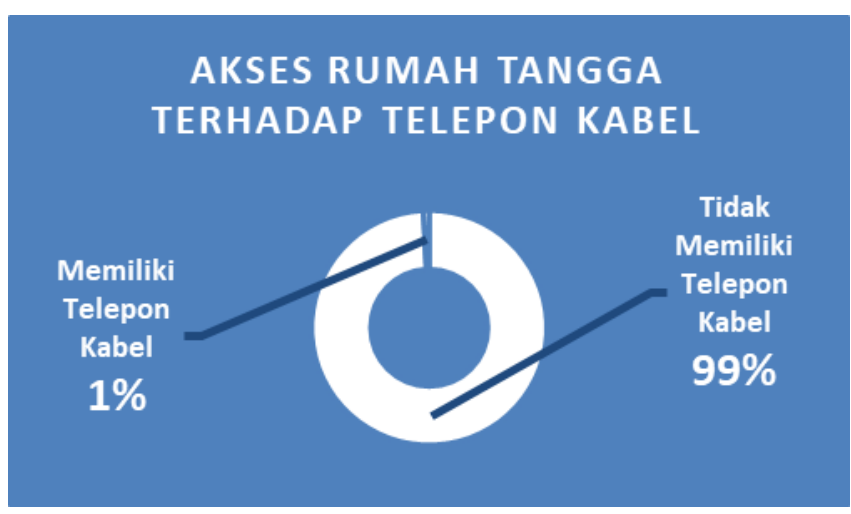

Gambar 7 Akses Rumah Tangga Terhadap Saluran Telepon Kabel

Akses rumah tangga terhadap saluran telepon kabel mayoritas sudah tidak ada yang memiliki dengan persentase $99 \%$. Berikut gambaran persentasenya:

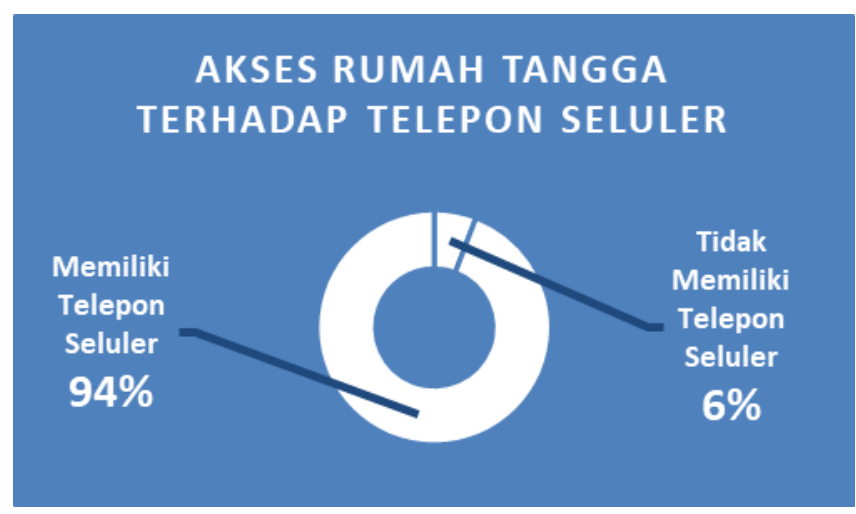

Gambar 8 Akses Rumah Tangga Terhadap Telepon Seluler

Berdasarkan temuan pada saat penelitian, pada umumnya masyarakat pernah memiliki akses 
penggunaan telepon kabel, namun saat ini layanan sudah tidak lagi disediakan oleh provider sehingga akses terhadap perangkat pun sudah tidak ada. Sebaliknya, akses rumah tangga terhadap telepon seluler meningkat dengan persentase $94 \%$.

Akses berikutnya yang diukur adalah kepemilikan rumah tangga terhadap perangkat komputer (desktop, laptop, tablet dan sejenisnya) dan internet. Berdasarkan hasil survey, 55\% rumah tangga di Kecamatan Barru tidak memiliki komputer, baik desktop, laptop, tablet dan sejenisnya. Ketersediaan komputer dalam sebuah rumah tangga menjadi salah satu tolak ukur TIK karena penggunaan komputer merupakan keterampilan yang sangat penting saat ini. Informasi ini dapat memberi masukan pada analisis dan desain kebijakan untuk mengatasi kesenjangan digital. Berikut adalah deskripsi akses rumah tangga terhadap komputer:

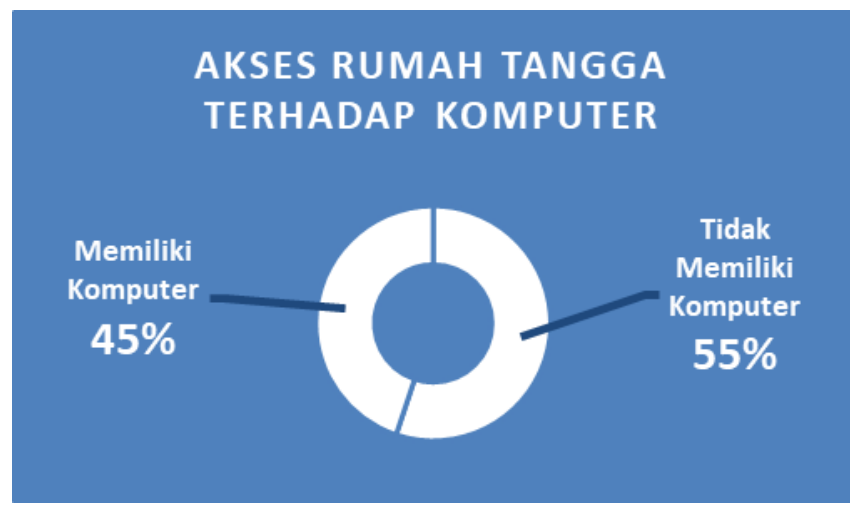

Gambar 9 Akses Rumah Tangga Terhadap Komputer

Indikator terakhir dalam pengukuran akses rumah tangga adalah internet. Berikut ini adalah deskripsi akses rumah tangga terhadap internet:

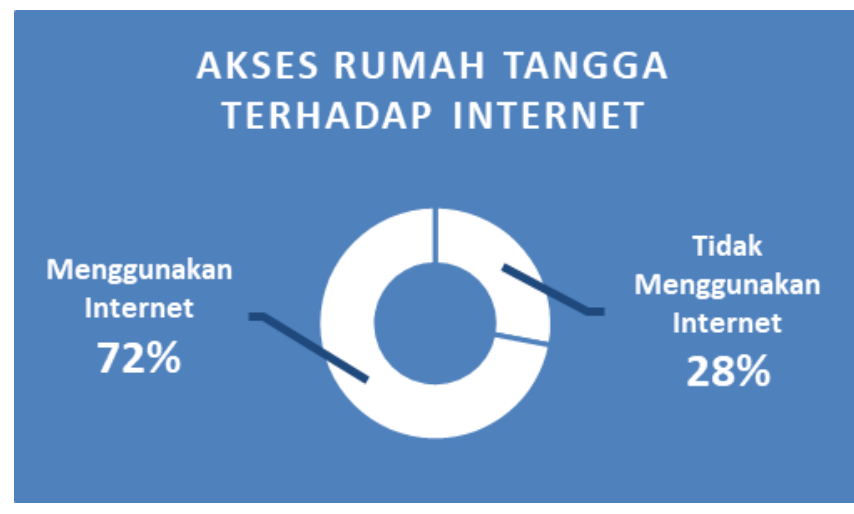

Gambar 10 Akses Rumah Tangga Terhadap Internet

Secara keseluruhan, berdasarkan hasil survey, 72\% rumah tangga di Kecamatan Barru telah menggunakan internet. Hal ini menunjukkan bahwa terdapat peningkatan indikator masyarakat informasi di wilayah tersebut. Kepemilikan internet merupakan indikator kunci dalam meningkatkan masyarakat informasi karena akses internet yang tersedia di rumah memberikan peluang kepada anggota keluarga untuk mendapatkan manfaat dari layanan internet.

Layanan internet yang paling banyak digunakan adalah adalah jaringan broadband seluler melalui SIM card yang diakses menggunakan telepon seluler (smartphone). Meskipun pemanfaatannya masih lebih banyak pada media sosial $(89 \%)$ dan belum banyak yang memanfaatkan untuk mendapatkan informasi atau pelayanan dari pemerintah $(10 \%)$.

Sementara itu, beberapa alasan rumah tangga tidak memiliki akses terhadap internet yang berjumlah $28 \%$ adalah tidak atau belum memerlukan internet sebanyak $46 \%$, kurangnya kepercayaan diri, pengetahuan atau keterampilan untuk menggunakan internet (38\%), biaya untuk membeli peralatan terlalu tinggi (26\%), biaya layanan yang terlalu tinggi (13\%), dan ada akses internet dari tempat lain (10\%). Jawaban-jawaban diperoleh tersebut merupakan jawaban berupa multiple answer (lebih dari satu jawaban).

\section{Karakteristik Individu}

Karakteristik individu diukur berdasarkan jenis kelamin, tingkat pendidikan tertinggi, dan status angkatan kerja. Gambaran karakteristik individu dapat di lihat dalam tabel di bawah ini:

Tabel 3 Karakteristik Individu

\begin{tabular}{|c|c|c|}
\hline No & Karakteristik Individu & Persentase \\
\hline \multirow[t]{4}{*}{1} & Jenis Kelamin & \\
\hline & Laki-laki & $36,3 \%$ \\
\hline & Perempuan & $63,7 \%$ \\
\hline & Total & $100 \%$ \\
\hline \multirow[t]{7}{*}{2} & Tingkat Pendidikan Tertinggi & \\
\hline & SD & $26,6 \%$ \\
\hline & SMP & $17,7 \%$ \\
\hline & SMA & $35,4 \%$ \\
\hline & Sarjana & $20,3 \%$ \\
\hline & Pascasarjana & $0 \%$ \\
\hline & Total & $100 \%$ \\
\hline \multirow[t]{5}{*}{3} & Status Angkatan Kerja & \\
\hline & Karyawan/Pegawai/Wiraswasta & $19,4 \%$ \\
\hline & $\begin{array}{l}\text { Pekerjaan yang tidak dapat } \\
\text { diklasifikasikan berdasarkan status }\end{array}$ & $37,6 \%$ \\
\hline & Pengangguran/Di Luar Angkatan Kerja & $43 \%$ \\
\hline & Total & $100 \%$ \\
\hline
\end{tabular}

(sumber: data hasil survey)

\section{Penggunaan TIK oleh Individu}

Penggunaan TIK oleh Individu diukur dari 4 aspek, yaitu penggunaan telepon seluler, komputer, internet, dan e-commerce. Berikut adalah hasil penelitian terhadap responden: 


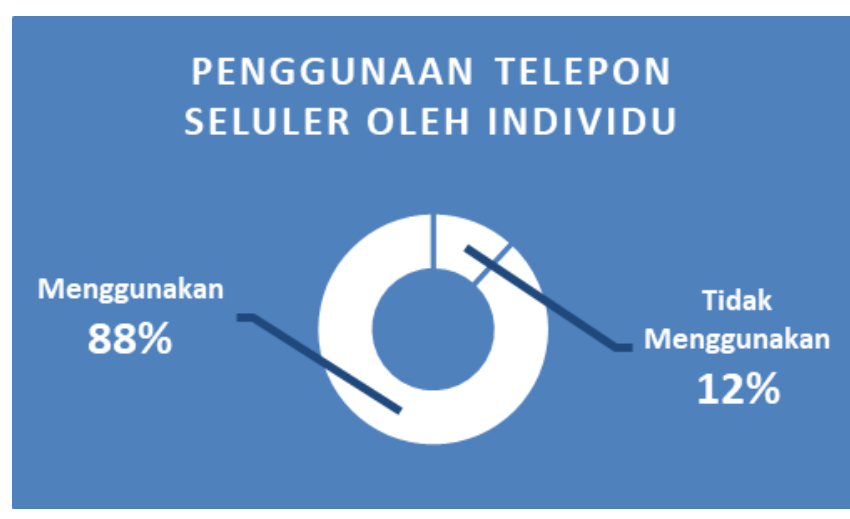

Gambar 11 Penggunaan Telepon Seluler Oleh Individu

Berdasarkan Gambar 11 dapat diketahui bahwa masyoritas masyarakat di Kecamatan Barru telah memiliki dan menggunakan telepon seluler (88\%). Angka ini berguna untuk menunjukkan perkembangan ekonomi suatu wilayah dimana akses dan penggunaan TIK masih terbatas. Indikator ini mengukur penggunaan teknologi seluler dan bertujuan untuk melengkapi indikator yang tersedia tentang jumlah pelanggan perangkat seluler.

Meskipun angka penggunaan telepon seluler sangat tinggi, tetapi angka penggunaan komputer oleh individu masih rendah (34\%). Indikator ini sangat terkait dengan keahlian yang merupakan salah satu ukuran IP-TIK. Kemampuan menggunakan komputer dapat meningkatkan keahlian TIK karena umumnya lebih sulit dari smartphone, dimana didalamnya ada aktivitas pengolahan komputer dasar dan pemrosesan data serta penggunaan internet. Berikut adalah gambaran persentase penggunaan komputer:

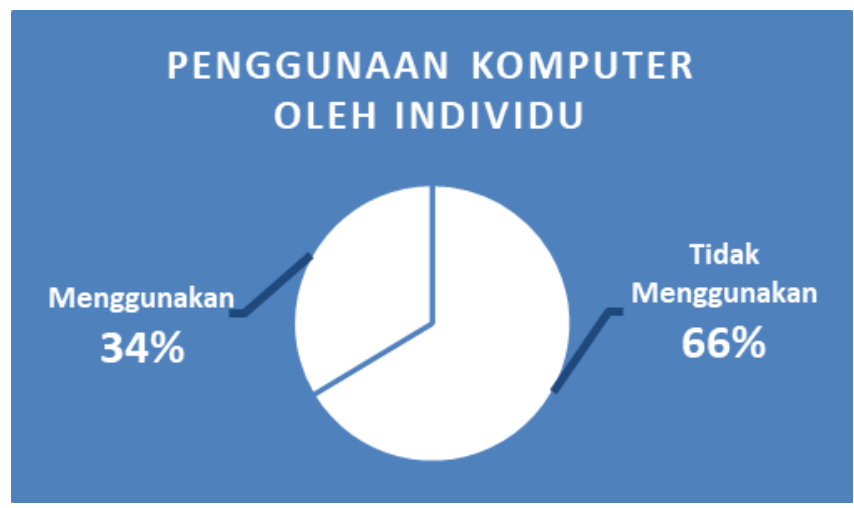

Gambar 12 Penggunaan Komputer Oleh Individu

Jika diukur berdasarkan aktivitas terkait penggunaan komputer, yang paling banyak dilakukan adalah menyalin atau memindahkan file atau folder (72\%), menggunakan Microsoft Word (56,5\%), dan mengirim e-mail dengan file yang dilampirkan (37\%), serta aktivitas yang paling sedikit dilakukan adalah menulis program komputer menggunakan bahasa pemrograman khusus (8\%). Jawaban yang diperoleh merupakan multiple answer (lebih dari satu jawaban).

Indikator berikutnya adalah penggunaan internet oleh individu. Berdasarkan persentase, mayoritas masyarakat Kecamatan Barru adalah pengguna internet dengan angka sebanyak $71 \%$. Angka ini merupakan indikasi yang mengarah kepada kemajuan Kecamatan Barru menuju masyarakat informasi, meskipun beberapa indikator lainnya seperti aktivitas penggunaan internet masih perlu ditingkatkan khususnya dalam hal bagaimana internet mampu mengubah cara seseorang dalam berbisnis, belajar, membeli, berkomunikasi dan berinteraksi, termasuk terhadap pemerintah. Kegiatan-kegiatan penggunaan internet pada aktivitas di atas yang tertinggi adalah partisipasi dalam jejaring sosial (89\%), streaming atau mengunduh gambar film, video atau musik, bermain atau mengunduh game (58\%), dan membeli atau memesan barang dan jasa (42\%). Berikut adalah gambaran persentasenya:

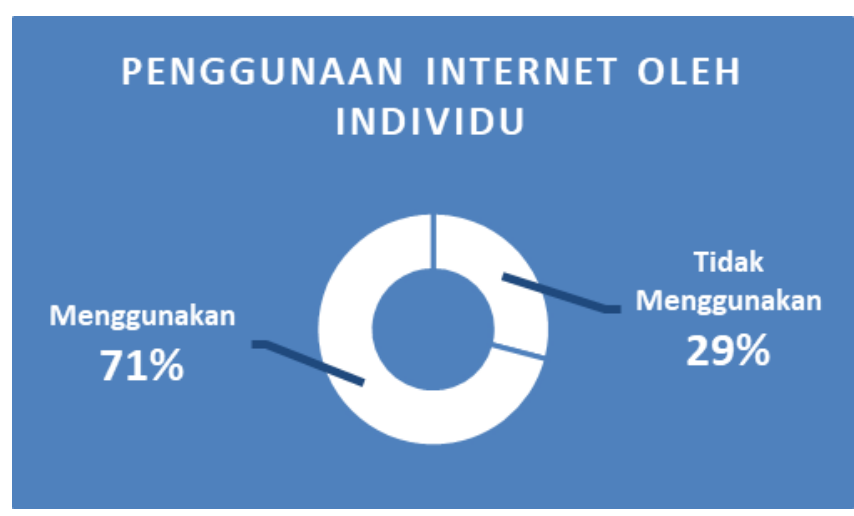

Gambar 13 Penggunaan Internet Oleh Individu

E-commerce merupakan indikator yang ditambahkan berdasarkan hasil revisi yang mengikuti perubahan di bidang teknologi informasi dan komunikasi. Pengguna e-commerce di Kecamatan Barru cukup tinggi yaitu $42 \%$ dengan pembelian terbanyak adalah produk fashion (37\%) dan metode pengiriman terbanyak menggunakan jasa ekspedisi sebanyak $(26 \%)$.

\section{KESIMPULAN}

Akses dan penggunaan TIK pada tingkat rumah tangga dan individu di Kecamatan Barru untuk persentase tertinggi adalah akses rumah tangga terhadap televisi sebanyak 95\%. Berikutnya akses rumah tangga terhadap telepon seluler 94\%, penggunaan telepon seluler oleh individu $88 \%$, akses rumah tangga terhadap internet $72 \%$, dan penggunaan 
internet oleh individu sebanyak 71\%. Sebaliknya, persentase terendah adalah akses rumah tangga terhadap radio sebanyak $14 \%$, penggunaan komputer oleh individu $34 \%$, dan akses rumah tangga terhadap komputer $45 \%$. Hasil ini menunjukkan bahwa penggunaan TIK di wilayah Kecamatan Barru sudah optimal yang dapat dilihat dari tingginya kepemilikan perangkat TIK. Disisi lain tingginya angka akses terhadap internet baik oleh rumah tangga maupun individu menunjukkan ada kemajuan ke arah masyarakat informasi di wilayah tersebut. Meski demikian, keahlian dalam hal TIK belum optimal yang dapat dilihat dari akses dan penggunaan komputer baik di tingkat rumah tangga maupun individu yang sangat rendah. Dalam perencanaan kebijakan TIK di Kecamatan Barru, indikator ini perlu diperhatikan untuk mendorong pengembangan TIK dalam berbagai sektor diantaranya pemerintahan, kesehatan dan perekonomian.

Sebagai rekomendasi untuk penelitian yang akan datang, penelitian ini tidak mengukur tingkat literasi digital masyarakat sehingga penting untuk dikaji lebih dalam disebabkan tingginya akses masyarakat terhadap internet.

\section{UCAPAN TERIMA KASIH}

Penelitian ini mendapatkan Dana Hibah dari Kementerian Riset, Teknologi dan Pendidikan Tinggi melalui skema Penelitian Dosen Pemula. Ucapkan terima kasih yang sebesar-besarnya kepada Kemenristekdikti dalam mendukung kemajuan penelitian di Indonesia. Ucapan terima kasih juga disampaikan kepada seluruh rekan kerja di Program Studi Ilmu Komunikasi Fakultas Ekonomi dan IlmuIlmu Sosial Universitas Fajar, LPPM Universitas Fajar dan seluruh Tim Peneliti atas segala dukungan dan masukan dalam pelaksanaan penelitian dan publikasi karya ilmiah ini.

\section{DAFTAR Pustaka}

Badan Pusat Statistik Kabupaten Barru. Kecamatan Barru Dalam Angka 2018. ISSN 2598-0513. No. Publikasi 73100.1808. Katalog BPS: 1102001.7310 .030

Berita Resmi Statistik. Badan Pusat Statistik. (2018). Indeks Pembangunan Teknologi Informasi dan Komunikasi (IP-TIK) Indonesia Tahun 2017 No. 102/12/Th. XXI

Damanik, Jarudo. (2016). Survey Penggunaan Teknologi Informasi dan Komunikasi Rumah Tangga Di Wilayah Kerja BBPPKI Medan Tahun 2016. Jurnal Teknologi Informasi dan Komunikasi, Vol. 5 No. 2, 93 - 108

Darwanto, Herry. (2012). Indeks Kesiapan Berjejaring Indonesia 2012. Retrived from https://www.bappenas.go.id/blog/indeks-kesiapanberjejaring-indonesia-2012

Fauzi, Yuliyanna. (2018). BPS Sebut Indeks Pembangunan Teknologi RI Rendah. Retrived from CNN Indonesia

International Telecommunication Union for Measuring ICT Access and Use by Households and Individuals. (2016). Manual for Measuring ICT Access and Use by Households and Individuals 2014 Edition. New ICT indicators on ICT access and use by households and individuals, 2014-2015, 26 May 2016.

Kriyantono, Rachmat. (2010). Teknik Praktis Riset Komunikasi : Disertai Contoh Praktis Riset Media, Public Relations, Advertising, Komunikasi Organisasi, Komunikasi Pemasaran. Jakarta : Kencana

Lampiran Surat Penerimaan Proposal dan Pengabdian Kepada Masyarakat untuk Pendanaan Tahun 2019 No. 2276/E3/LL/2018 Tanggal 24 Juli 2018

Manual for Measuring ICT Access and Use by Households and Individuals new ICT indicators on ICT access and use by households and individuals, (2018)

Yusrizal. 2016. Survey Penggunaan Teknologi Informasi dan Komunikasi di Wilayah Perbatasan. Jurnal Teknologi Informasi dan Komunikasi Vol. 5 No. 1, 13 -28 . 